\title{
THE SUBSCRIPTION OF STATILIUS MAXIMUS TO CICERO, DE LEGE AGRARIA*
}

\author{
ORLA FIONA MULHOLLAND
}

\begin{abstract}
In his 1983 edition of Cicero, De lege agraria, Václav Marek proposed a new interpretation of the ancient editorial subscription by the classical grammarian Statilius Maximus that is transmitted together with these speeches. Marek's interpretation greatly improves our understanding of this important record, which is the earliest known editorial subscription to any text of the Latin classics. However, Marek's reading has not been widely noticed or adopted. The present contribution explains why it is preferable to the conventional interpretation of the subscription, on grounds of manuscript transmission, language, and the practicalities of ancient editing.
\end{abstract}

Keywords: editorial subscription; Statilius Maximus; Poggio Bracciolini; Cicero, De lege agraria; Vaticanus latinus 11458; paratext

The ancient editorial subscriptions transmitted in some manuscripts of the Latin classics originate in the late antique period, with one exception: the notice appended to the text of Cicero's speeches De lege agraria by Statilius Maximus, an author cited in the grammatical tradition who is approximately datable to the second century AD. ${ }^{1}$ The subscription is remarkable not only for this early date, but also for Statilius' report that he consulted the text of Tiro, Cicero's secretary. ${ }^{2}$ The interpretation of this short editorial

* I wish to thank M. Bažil and I. Prchlík for the opportunity to present this paper here and the journal's anonymous referees for useful suggestions and corrections.

1 On the subscriptions in general see Reynolds, Wilson (2013: 39-43, with further literature at 254-255); the most comprehensive study of them is by Cameron (2011: 421-526, here esp. 427-429). The Latin subscriptions to classical texts are edited by Zetzel (1981: 211-227), cf. the convenient overview of these in Büchner (1961: 355-357). On Statilius see Schmidt (1997), Wessner (1930), Schanz, Hosius, Krüger (1922: 164-165); his grammatical work on rare words in Cicero, fragments of which are transmitted by Julius Romanus ( $3^{\text {rd }}$ cent. AD), has been studied by Uría Varela (2012), De Paolis (2000: 41-43), Merello (1977), Zetzel (1974).

2 The principal discussions of the subscription are by Pecere (1982, briefly revisited in Pecere 1986: 29-30) and Zetzel (1973: 225-230). The notice is discussed in most surveys of ancient scholarship, from Birt (1882: 123-125) to Reynolds, Wilson (2013: 31-32). See also the works cited in the next note. That the edition of Tiro consulted by Statilius was a later fake is suggested by McDermott (1972: 
note throws up a series of problems, yet scholarship on it has almost entirely overlooked an elegant solution to many of them which was proposed by V. Marek in his Teubner edition of the Agrarian speeches. Marek's novel interpretation is proposed in a few lines of the Latin preface to his edition - which is no doubt why it has been missed by most subsequent research ${ }^{3}$ - and that setting precluded the presentation of full supporting argument. A Festschrift for Professor Marek provides an apt occasion to explain in detail why his interpretation of the Statilius subscription should be generally adopted and to show how it reveals this ancient notice to be even more interesting than had hitherto been realized.

\section{I.}

The orations De lege agraria are among eight speeches of Cicero found by Poggio Bracciolini in 1417 during the Council of Constance. The books in which he found them are now lost, but Poggio's own transcript of the texts is extant in the Vatican. In this manuscript Poggio entered the following marginal note at the start of Leg. agr. II: ${ }^{4}$

In exemplari vetustissimo hoc erat in margine. Emendavi ad tyronem et laecanianum / acta ipso cicerone et antonio coss. oratio xxiiii. In exemplo sic fuit. statilius / maximus rursum emendavi ad tyronem et laecanianum et dom. \& alios veteres. iii. / oratio exi / mia.

In the oldest exemplar this was in the margin. I have emended from Tiro and Laecanianus. Delivered when Cicero himself and Antonius were consuls. Speech 24. In the exemplum it was thus. I, Statilius Maximus, have again emended from Tiro and Laecanianus and Dom. and 3 other old authorities. Outstanding speech.

Discussion of this notice has focused on the nature of the 'emendation' here recorded, or the identity of Laecanianus, about whom (or what) we know nothing but this reference, and 'Dom.', the latter plausibly but speculatively identified with a Domitius Balbus whom Fronto cites in the same breath as Tiro as an early editor of Cicero. ${ }^{5}$ Though textual conjectures have been proposed for individual words or phrases, ${ }^{6}$ no one aside from

$278-280$, at 280) and argued in detail by Zetzel (1973: 230-243), but the latter's evidence for this is refuted by Timpanaro (1986: 200-209).

3 Marek (1983: VI-VII). Coraluppi (1987: 465), reviewing Marek's edition, found this proposal noteworthy, but the subsequent discussions of the subscription (Martin 1984; Pecere 1986; Piacente 1992-1993, revised as Piacente 2014; Schmidt 1997; Pöhlmann 2003: I, 74-75; Röhle 2005; Cameron 2011; Reynolds, Wilson 2013) appear to be unaware of it.

4 MS. Vaticanus latinus 11458, fol. 56v, upper margin; the two short lines at the end are in the right margin beside the text of the speech. On this much discussed manuscript, see in brief Rouse, Reeve (1986: 83-85 and 91; on this subscription at 84) and Campana (1973). Description and bibliography by Gilles-Raynal, Dolbeau, Fohlen, Riou, Tilliette (2010: 808-810).

5 For the Fronto passage, see n. 19 below. An alternative expansion (Clark 1909b: ix), entertained by McDermott (1972: 279) and Merello (1977: 114-115), is Dom(inus), referring to Statilius' own teacher, employer, or former slavemaster, but the implication of et alios veteres is that Dom. must likewise be one of the veteres, i.e. textual authorities from an earlier era. I discuss these and other questions in a separate note, to appear elsewhere.

6 Röhle (2005), Piacente (1992-1993: 97-100 = 2014: 94-96), Zetzel (1973: 228-230) all debate the word eximia and the numeral xxiiii; Badian (ap. Zetzel 1973: 230 n. 24) proposes Balbum for \& alios to restore the name Dom(itium) Balbum (setting veteres iii in apposition to the three names). 
Marek has questioned the structure of the note as a whole. The conventional reading of the text, followed by every other scholar, is to take the two sentences In exemplari vetustissimo hoc erat in margine and In exemplo sic fuit to be comments added by Poggio, each introducing a separate subscription by Statilius. Using modern typographic conventions we could express this interpretation as follows:
Poggio: In the oldest exemplar this was in the margin:
Statilius: 'I have emended from Tiro and Laecanianus. Delivered when Cicero himself and Antonius were consuls. Speech 24.'
Poggio: In the exemplum it was thus:
Statilius: 'I, Statilius Maximus, have again emended from Tiro and Laecanianus and Dom. and 3 other old authorities. Outstanding speech.'

The problems raised by this interpretation concern both Poggio and Statilius. Poggio says the first subscription was 'in the margin', so it has been assumed that he must have found the other one somewhere not in the margin, i.e. in the body of the text, but could in exemplo really express that sense? Or do exemplar and exemplum refer to two different manuscripts? Ingenious interpretations have been offered along these lines, but, as will be shown below, they do not succeed in explaining the use of terms here. And as regards Statilius we must ask: why would he twice (rursum) have corrected his text against those of Tiro and Laecanianus? Why would a collation need to be done twice? Again, parallels have been claimed, but none match the odd situation apparently presented by this double subscription.

Yet, as Marek observed: 'incertum est an ... Statilius Maximus ... ipse duas emendationes fecerit, primam duo exemplaria, secundam sex exemplaria sequens; verisimilius autem videtur ipsum primam subscriptionem iam in uno ex exemplaribus suis invenisse'. ${ }^{7}$ Following the second alternative suggested by Marek, we would instead read the text as follows:

$\begin{array}{ll}\text { Poggio: } & \text { In the oldest exemplar this was in the margin: } \\ \text { Anon. ed.: "I have emended from Tiro and Laecanianus. Delivered when Cicero himself } \\ \text { and Antonius were consuls. Speech 24." } \\ \text { Statilius: } \\ \quad \text { In the exemplum it was thus. I, Statilius Maximus, have again emended from } \\ \text { Tiro and Laecanianus and Dom. and } 3 \text { other old authorities. Outstanding } \\ \text { speech.' }\end{array}$

That is, the text 'I have emended from Tiro... Speech 24' would have been found by Statilius in his source. Statilius copied it out, noting in the source (exemplum) it was thus.' And then, echoing the subscription in front of him, he added one of his own: 'I, Statilius Maximus, have again emended from Tiro... Outstanding speech.' This double subscription, the first part by the anonymous editor recorded in Statilius' source, and the second part by Statilius himself, would then have been transmitted as a unit and found by

Marek (1983: VI): 'It is uncertain whether ... Statilius Maximus ... himself had carried out two emendations, the first based on two sources, the second on six; it seems more likely, rather, that he himself found the first subscription already in one of his sources'. 
Poggio. Poggio himself would thus have added only the initial observation that it was in the margin of the exemplar vetustissimum, the oldest (or 'a very old') exemplar.

On this reading we no longer need to read subtle semantic distinctions into the two terms exemplar and exemplum, as the difference would simply be of two different writers 1200 years apart each naturally using somewhat different idioms to refer to a manuscript source. And we no longer need to explain why a single editor has apparently done the same tasks twice over.

Even just on this brief review of the two interpretations, Marek's seems preferable. Yet, since it stands opposed to the unanimous view of nearly two and a half centuries of scholarship, from Bandini in the eighteenth century down to the most recent examinations of the subscription, detailed argument is appropriate. In the following, this will be presented in three areas: the textual transmission of the notice, its language, and the practicalities of editorial work in the ancient world.

\section{Transmission}

Versions of the notice appear in a number of manuscripts, but study of the whole transmission of the works Poggio found has shown that the text in his manuscript of 1417 is the sole source of all the other copies of the subscriptions. ${ }^{8}$ However, Poggio's original autograph copy was only identified as such in the later twentieth century, by which time two hundred years of scholarship had already built an interpretation on less reliable sources. The rediscovery of our earliest version of the text should have prompted a re-evaluation of its overall structure, because the layout in Poggio's manuscript is significantly different from the one familiar from the previous literature. ${ }^{9}$

The modern discussion of the notice has been shaped above all by the corpus of Latin subscriptions edited by $\mathrm{O}$. Jahn in the mid-nineteenth century, which remained the standard reference edition of these texts until the 1980s. ${ }^{10}$ In Jahn's text the layout leaves no room for ambiguity in the structure of the note: with typographical overkill (indentation, different font sizes, italic vs. roman script), the text is divided into two separate subscriptions, each with an introductory comment emphatically marked off as distinct from the subscription itself. It is impossible not to read such a text as what has become the conventional interpretation of the note.

In contrast, Poggio's original version is written as continuous text without any internal distinctions in the layout nor any hierarchy between the elements of the text. ${ }^{11}$ The only indentation is a hanging indent of the first line of the whole notice; otherwise line-breaks occur only where the space runs out at the edge of the page. The last two

8 The dependence of all the relevant manuscripts on a lost text of Poggio's was established already by Clark (1909a) long before the missing codex was identified in the Vatican by Campana (1973) as the manuscript Vaticanus latinus 11458; although a few manuscripts of Leg. agr. are wholly independent of Poggio's copy (on which see Coraluppi 1983), none of them includes anything resembling this notice.

9 Zetzel $(1973 ; 1981: 211)$ corrects erroneous readings, but neither he nor Pecere (1982: 74) alters the inherited layout or questions the structure.

10 Jahn (1851: 329-330, no. 1); provisionally updated, for the Latin secular texts, by Zetzel (1981: 211-227).

11 See the photographs in Pecere (1982: Tav. X.2) and Zetzel (1973: Plate II). 
words are squeezed into the right-hand margin and these words are marked off from the text of the speech by a dividing line, but this is evidently to avoid anyone mistaking them for text or variants of the speech itself and has no bearing on the internal organization of the note.

The only internal mark of structure within Poggio's text is capitalization. Three initial capitals are emphatically distinguished from the rest of the text in size and form, being majuscules three times taller than the minuscules of the rest of the text. They divide the notice into three units, each beginning with a capital, and these units match the three 'speakers' of Marek's interpretation: Poggio (In exemplari hoc erat in margine.), the anonymous editor (Emendavi... oratio XXIV.), and Statilius (In exemplo... oratio eximia.). It is notable that the word statilius, which on the traditional reading would be the first word of the second subscription by Statilius, is not capitalized. ${ }^{12}$ Had Poggio wished to mark off In exemplo sic fuit as his own words, he would surely have capitalized the next word - statilius - to mark the beginning of the second text he supposedly found, to set it parallel to Emendavi. The absence of capitalization here encourages us to read from In exemplo sic fuit. statilius... to the end as a single unit, with the first-person voice of Statilius consequently applying also to that first sentence.

The conventional reading was not an invention of Jahn's. His text depended on a publication by A. Mai a few decades earlier, which was in turn influenced by Bandini's reports of manuscripts in Florence. Each of these three scholars appears to have added somewhat to their material, each accentuating the interpretation more forcefully than the last. ${ }^{13}$ But some secondary manuscripts do indeed present the subscription in a layout that implies, at least faintly, what has become the conventional interpretation. ${ }^{14}$ The oldest of these is an early fifteenth-century Florentine codex with links to Poggio's own circle. ${ }^{15}$ Yet we can exclude the possibility that its interpretation could hence reflect 'inside information' communicated orally by Poggio. The annotator who added the notice to this manuscript, and who thus seems to be the originator of the 'modern' interpretation of the subscriptions, has also recorded uncertainty over whether one of the texts was found in France or Germany, in response to a hint in Poggio’s autograph. ${ }^{16}$ If our annotator could not even

12 Zetzel's (1973: 227) diplomatic transcript is erroneous in capitalizing this word.

13 Mai (1817: 230-231 and 236) is reporting two Ambrosian MSS., one of them wholly inaccurately (C 236 inf, fol. 28r, in which the layout presupposes Marek's interpretation); I have not seen the other (C 96 sup). Bandini in some cases (1775: 431-432 and 453-454) adds punctuation that reinforces the reading subsequently adopted by Mai, though his reports of the notice in other manuscripts are presented in a way that matches the interpretation of Marek (Bandini 1775: 434 and 441; 1776: 657).

14 E.g. in the manuscript Laurentianus pluteus 48.26, fol. 15v, Statilius is capitalized and there are paragraph marks before In exemplari... and In exemplo..., encouraging us to read these as each introducing a separate subscription.

15 Laur. plut. 48.26 (on which see previous note); Reeve (1995: 62) observes that this manuscript was partly written by Guglielmino Tanaglia, a friend of Poggio's closest intellectual collaborator, Niccolò Niccoli.

16 Laur. plut. 48.26, fol. 64v: the first scribe has noted that the end of one speech (Pro Roscio comoedo) is missing, and the annotator adds quia non erat plus in exemplari quod ex Gallia seu Germania habuimus ('because there was no more in the exemplar that we had from France or Germany'); this echoes a note in Poggio's manuscript, recording that he had found the speeches perquisitis plurimis Gallie Germanieque ... biblyothecis ('after searching many libraries in France and Germany', Vat. lat. 11458, fol. $94 \mathrm{r})$. 
ask Poggio which country he found the texts in, he certainly was not able to quiz him for additional information on the layout of their marginalia.

The traditional interpretation is thus revealed to be no more than a humanist conjecture, whereas the only authoritative source of the text invites us instead to read it with Marek.

\section{Language}

This is not the only annotation about sources that Poggio added to his manuscript of 1417. Seven other short notes record brief details of damage or missing text in the now lost manuscript(s) from which he copied the newly discovered speeches. Hence, even with such a tiny scrap of text, we can usefully compare its language to that of the other notes, as well as to Poggio's wider linguistic habits. ${ }^{17}$

The difference in interpretations comes down to whether the words In exemplo sic fuit are by Statilius in the second century or Poggio in the fifteenth, so it is of interest that this phrase uses classical verb-final word order, for Poggio a stylistic flourish that he tends reserve for markedly classicizing contexts. The other source-notes, including the initial words of this note (In exemplari vetustissimo hoc erat in margine.), match Italian word order, as was Poggio's usual practice in unmarked 'everyday' Latin of this kind. ${ }^{18}$

But the key issue is the pair of terms exemplar/exemplum. These are found in editorial contexts in both classical and Renaissance Latin, but usage in the two periods differs. It is easy to ascribe exemplum here to Statilius, because it is one of the regular classical terms for a manuscript source and is found again in the same sense even within the tiny corpus of subscriptions to the Latin classics. ${ }^{19}$ By the Renaissance, however, following mediaeval usage, there is a clearly predominant use of the pair exemplar/exemplum as the antonyms 'source' (exemplar) vs. 'copy' (exemplum). Although other senses are attested in humanist Latin, they are very much exceptions to a well established norm. ${ }^{20}$ Hence, if the conventional interpretation of the subscriptions is to be maintained, some special

17 The annotations are studied in detail by Pecere (1982) and recorded in the manuscript description by Gilles-Raynal, Dolbeau, Fohlen, Riou, Tilliette (2010); some are omitted in the older catalogue by Ruysschaert (1959).

18 This is a tendency rather than a strict rule in Poggio, but is still indicative; see Rizzo (2004: 61) on his habit of using Italian word order in Latin texts of purely functional scope. (This accordingly does not apply to Poggio's own two self-aggrandizing subscriptions in this manuscript, which, in contrast, consciously echo classical inscriptions in vocabulary and word order, on which see Campana 1973.)

19 ThLL V/2, 1349, 62-66 (s.v. exemplum), Kornhardt (1936: 54-55). One should note esp. Statilius' $2^{\text {nd }}$-cent. contemporary Fronto ad M. Caes. 1, 7, 4 (Van den Hout, p. 15), who refers to Ciceronian manuscripts of Tiro, and perhaps also the 'Dom.' of our subscription (cf. n. 5 above), as exempla aut a Tirone emendata aut a Domitio Balbo descripta aut ab Attico aut Nepote ('manuscripts either emended by Tiro or written by Domitius Balbus or by Atticus or Nepos'). Among the other Latin subscriptions to the classics (all late antique, here cited in the numbering of Zetzel 1981: 211-227) there are only eight references to a source-manuscript: once using exemplum (no. 3), against codex four times (nos. 9, 13, 22, 25), and once each for exemplar (no. 11), exemplarium (no. 7), and antigraphum (no. 4).

20 Although Rizzo (1973: 185-192) records the range of possible (opposed, synonymous, overlapping) Renaissance uses of the two terms, she stresses throughout her discussion that the opposition of exemplar as 'source' to exemplum as 'copy' is the standard usage in humanist philological contexts. For the mediaeval background to this usage see the notarial handbook quoted below (n. 25), of special relevance to Poggio, a notary by training. 
explanation is needed for Poggio's unexpected choice of the pair exemplar/exemplum to refer to his source(s) here. ${ }^{21}$

Two attempts have been made to offer such an explanation, by J. Zetzel and O. Pecere. Zetzel, assuming that the two introductory comments refer to a position in the margin and the main text respectively, argues firstly that the pair exemplar/exemplum can express the opposition between the physical book and the immaterial composition, and secondly that this opposition could refer to the distinction between the margin and the main text. ${ }^{22}$ Neither point holds. Even if we were to grant Zetzel's claim about usage, different positions on the page can hardly be expressed as a distinction between the material and the immaterial, as no part of the page layout is any more or less physical than any other; ${ }^{23}$ if at all possible - understanding exemplum as 'the words, not the form' 24 - this interpretation would mean that the second subscription was embedded within the text of the speech, but even this rather strains the claimed material/immaterial distinction.

However, the parallels cited by Zetzel as examples of this usage are anyway all instances of the familiar sense of exemplar as original and exemplum as copy. ${ }^{25}$ The material/ immaterial opposition of the two terms is indeed attested in the fifteenth century, but only by L. Valla, who is no guide to Poggio's Latinity, which was the specific target, as a model of bad Latin, that Valla aimed to reform. And in this case Valla castigates even Ovid for his 'errors' in failing to observe this use of the terms, so it is clear that it is a prescriptive norm proposed by Valla himself, not an observation of usage. ${ }^{26}$ While it may have influenced subsequent writers, it has no bearing on a text from 1417 , decades before Valla's Elegantie were written.

In the other attempt to explain Poggio's use of exemplum here, Pecere accepts the usual Renaissance sense of exemplar/exemplum as the pair of antonyms 'original'/'copy', but argues that here they refer to two different manuscripts, one the copy of the other. ${ }^{27}$ It

21 Among the other source notes in his manuscript of 1417, Poggio uses exemplar twice, never exemplum (see $\mathrm{n} .28$ below).

22 Zetzel (1973: 227).

23 Thus already Pecere (1982: 88).

24 Zetzel (1973: 227 n. 10).

25 Zetzel (1973: 227 n. 10) cites the $13^{\text {th }}$-cent. Bolognese notarial writer Rolandinus de Passageriis (via Du Cange, Carpentier, Henschel, Favre 1883-1887: s.v. exemplar), who states unambiguously that the exemplar is the original text (originalis scriptura), the exemplum that which is drawn or generated from the earlier or original text (exemplum ... est scriptura exemplata, generata, vel sumpta ex priori sive originali scriptura); and a letter of Poggio (Tonelli 1832: I, 199) which says he has appended a copy (exemplum) of some letters he had sent to other friends. For the physicality of exemplar Zetzel cites a letter of Poggio (Tonelli 1832: I, 175-176) asking for an exemplar of the works of Seneca; it is clear from the context and stated outright in the following letter (lib. II, ep. 39: Tonelli 1832: I, 176) that the manuscript is being sought specifically as a model for a scribe to copy. Zetzel does not explain how he derives a material/immaterial distinction from these texts.

26 L. Valla, Elegantie VI, 33 (ed. Garin 1962: 214-215), discussed by Rizzo (1973: 191): exemplum incorporale est, exemplar plerunque corporale ('exemplum is incorporeal, exemplar mostly corporeal'). This whole chapter by Valla is an attempt to determine the difference between the two terms in the classical era: Valla argues that in Cicero's letters exemplar is used de pagina scripta, quod corporale est ('of the written page, which is corporeal'), whereas exemplum is used de sententia, quae in pagina continetur, vel potius ex pagina percipitur ('of the thought that is contained in the page, or, rather, is perceived from the page'). In origin exemplar is an adjectival form derived from exemplum (ThLL V/2, 1320, 36-38 [s.v. exemplar]), so there was in fact no firm semantic distinction between the two words in classical times; cf. Kornhardt (1936: 52-59).

27 Pecere (1982: 87-89). 
is certainly plausible that, as Pecere argues, exemplar vetustissimum is here used to denote some anterior copy reported in an annotation but not directly seen by Poggio, but we are still left with the unanswered question of why he then chose to call his direct exemplar an exemplum. Earlier in the manuscript two notes to the speech Pro Rabirio perduellionis reo report gaps in, respectively, an exemplar vetustissimum and a plain exemplar, ${ }^{28}$ so why did Poggio not use this pair again in relation to Leg. agr.? The choice of exemplum for the direct source in the case of Leg. agr. remains anomalous and needlessly confusing: Poggio's own direct exemplar would be termed an exemplum because it had once upon a time been someone else's copy. This seems little more than an ingenious way to acknowledge the conventional Renaissance meaning of exemplum (= copy, apograph), yet to force it to mean the opposite, i.e. source, or exemplar.

To conclude: the very fact that In exemplo sic fuit would be routine language for Statilius but an unusual use for Poggio is itself an argument in favour of ascribing it to the former, not the latter. But, as we have seen above, even when we try to entertain the less likely attribution to Poggio, the attempt to make sense of his word-choice leaves us tied in knots of improbable and inconsistent interpretations.

Further, if we accept the reconstruction of either Zetzel or Pecere and suppose that Poggio found one subscription in the margin and the other embedded in the text (Zetzel), or one in a scholiast's note and the other in the regular writing area (Pecere), we must assume that the double subscription, originally transmitted as a unit, had been been broken up into two parts through scribal error, and one part then restored in the margin by a scholiast and/or corrector. Such errors are certainly possible, but it is a general rule in textual criticism that the more one has to posit complex chains of error and correction to justify a conjectured reading, the more one should question the correctness of the conjecture. In contrast, Marek's reading economically supposes Poggio to have found both subscriptions joined together as a single notice, which Zetzel and Pecere both agree must have been the original form. ${ }^{29}$

\section{Ancient editorial practice}

As noted at the outset, a practical problem is posed by the traditional interpretation of this note as comprising two subscriptions both composed by Statilius, namely the question of why he would have twice collated his text against two of the authorities he names, Tiro and Laecanianus. Pecere cites as parallel some subscriptions in which a single editor records working on the text a second time. In some of these the repetition is expressed simply by the use of the word relegi ('I have re-read'), ${ }^{30}$ but in the most explicit case, a subscription to Apuleius, the subscriber gives the two separate dates of his editorial work and even uses the word rursus, like Statilius' rursum:

28 Vat. lat. 11458, fol. 11v, in exemplari vetustissimo deficit una pagina ('in the oldest exemplar one page is lacking'), and fol. 14r, in exemplari deficiunt due charte que fuerunt abscise ('in the exemplar two sheets are lacking which have been cut out').

29 Note that the linguistic and text-critical objections presented above to Zetzel and Pecere's reconstructions apply equally to the interpretation of Cameron discussed below.

30 E.g. relegi meum, 'I re-read my (text)', in subscriptions to Boethius (Zetzel 1981: 211-227, no. 13). 
Ego Salustius legi et emendavi Romae felix Olibrio et Probino v. c. cons. in foro Martis controversiam declamans oratori Endelechio. rursus Constantinopoli recognovi Caesario et Attico conss. ${ }^{31}$

Yet these examples do not present a parallel to Statilius' case, because nowhere else do we find a second collation against the same text. We often go over our own texts a number of times, but that is not the same as to re-do a collation against a specific model. Collation against a specific text should not need to be done twice.

Pecere counters this problem with the claim by G. Pasquali that all collation before Lachmann was occasional in nature and was pursued only to solve specific problems in a text, i.e. the two collations, being localized and unsystematic, need not have overlapped. ${ }^{32}$ Firstly we may query to what extent Pasquali's sweeping claim holds at all: pre-modern collations did not characteristically record every single variant and instead selected readings judged interesting, but that is certainly not to say that no one before 1850 ever thought to collate a manuscript from start to finish. ${ }^{33}$ So we still need to explain why Statilius would later have recanted his earlier judgement of which readings to adopt and hence decided to conduct the whole exercise again.

But, crucially, Pasquali was not discussing subscribed texts, but rather the common reading practices by which textual traditions acquired new variants in antiquity. ${ }^{34}$ The very fact of recording the emendation of a text in a subscription implies a degree of method and system quite different from the desultory norm assumed in Pasquali's comment. And that this notice is among the rare cases that also record the sources used lifts it yet further from any such presumed everyday reading habit and sets it in a context of planned and systematic scholarly activity. For this and other reasons, Cameron brackets this notice with Greek scholarly practice rooted in the Alexandrian critical tradition, rather than with the more amateur efforts of the late antique Latin subscribers. ${ }^{35}$ Classing this notice as 'the only subscription we have to a scholarly edition,' Cameron observes that, '[Statilius] does not say legi, relegi, or recognovi ['I have read', 'I have re-read', 'I have checked', as in the late antique subscriptions], and for a good reason: he was not performing the routine activity these terms designate, but marking the completion of a genuinely philological enterprise. ${ }^{36}$ If anyone in antiquity was exempt from Pasquali's gener-

31 Zetzel (1981: 213, no. 3): 'I, Salustius, have read and emended (this text) successfully at Rome, in the consulate of Olibrius and Probinus, vir clarissimus [an honorific title], in the forum of Mars while declaiming a controversia to the orator Endelechius. Again at Constantinople I checked (the text) in the consulate of Caesarius and Atticus.' The two consular dates are AD 395 and 397 respectively.

32 Pecere (1982: 111-112 n. 108), citing Pasquali (1971: 343), who remarked: 'Ci si meraviglia come mai nell'una e nell'altra recensione siano rimasti tanti errori? Ma le collazioni antiche come quelle medievali, come quelle umanistiche, come ogni collazione sino al Lachmann, erano saltuarie: l'editore o il possessore ricorreva a un altro esemplare, quando un passo gli faceva sorgere un dubbio sulla correttezza del proprio.'

33 Timpanaro (1981) offered a more subtle picture of the work of pre-modern editors than was accepted in Pasquali's day, modifying the previous view that modern editorial method sprang to life fully formed in Lachmann's 1850 edition of Lucretius.

${ }^{34}$ His comment is made in the context of a discussion of textual contamination in the ancient transmission of Plautus.

35 Cameron (2011: 427-429), also noting parallels with Statilius' phrase alios veteres in the older Greek material.

36 Cameron (2011: 471 and 481). 
alization, then surely Statilius was. ${ }^{37}$ Indeed, Pecere himself later observes that the repeat emendation and the number of texts used by Statilius implies fastidiousness to the point of pedantry. ${ }^{38}$ It is hard to suppose that this fastidious pedant, when first presented with the manuscript of Tiro himself, lacked the curiosity and concentration to work through the whole text. There seems no reason why the first emendation against two of his sources would have been important enough for such a scholar to record it in a subscription and yet have been done so inadequately that he had to repeat it later.

A remaining possible interpretation is implied rather than spelled out by Cameron. His treatment of this notice assumes that the original form was a single subscription comprising elements of both the transmitted versions. ${ }^{39}$ Although he never directly addresses the point, he is presumably treating the two forms reported by Poggio as transmission variants of a single subscription by Statilius. Yet this leads him into contradictory accounts of Statilius' editorial practice. To explain the presence of the word rursum ('again') in a single subscription, Cameron maintains that this refers to re-checking the text rather than to the collation against the cited authorities. ${ }^{40}$ Yet, as quoted above, Cameron has persuasively argued that such routine editorial tasks as proofing one's own text (recognoscere) are precisely not what Statilius is recording here. ${ }^{41}$ However one wishes to reconstruct a single text from the two transmitted ones, rursum must be taken with emendavi, the only verb, so it is the philological emendation that is said to have been done 'again'. If we reconstruct a single subscription containing rursum emendavi, we would need to posit a previous, now lost subscription recording a first emendation. As one such is in fact transmitted, we can spare ourselves the trouble.

All in all, the conventional reading yields an unlikely and contradictory picture of Statilius' editorial practice, whereas the double collation is easily explained if we assume that two different editors produced the two subscriptions: while Statilius would have had no reason to distrust a prior collation of his own, he would be likely to doubt the reliability and judgement of some other, unknown scholar and to want to undertake his own comparison with the older authorities. Further, when he found this subscription, it could already have been copied many times down a chain of prior sources, and so new errors would have entered the text during that process of copying, all of them subsequent to the first collation against Tiro and Laecanianus; it would still be necessary for Statilius to check his copy against those authoritative older texts to remove the new errors.

37 Pasquali (1971: 478) shares Cameron's disdain for the intellectual level of the late antique subscribers, but does not comment on the Statilius subscription.

38 Pecere (1986: 29): 'con uno scrupolo che rasenta di pedanteria, controllò nuovamente il testo utilizzando altri quattro modelli emendati da specialisti'.

39 Cameron (2011: 427).

40 Cameron (2011: 450): 'Just as modern writers normally read proofs more than once, so a careful ancient corrector would often check his copy more than once. Statilius Maximus claims to have corrected Cicero's De lege agraria "again" (rursum emendavi).' He clarifies: 'Although Statilius claims to have used six manuscripts, the rursum means that he checked his own copy twice.'

41 Cf. also Cameron's response to Martin (1984), who saw links between this subscription and the everyday practice of proofing legal documents: Cameron (2011: $481 \mathrm{n} .130)$ observes that, whereas the phrase legi et recognovi, common in the late antique literary subscriptions, does indeed derive from this documentary practice, Statilius' term - the philological emendavi - has no connection to it. 


\section{Conclusion}

No one has ever offered an explicit defence of the traditional reading of the 'Statilius subscription', which has simply been taken over without question from the previous literature. We may suspect that the scholars whose views have been surveyed above would have seized on Marek's interpretation with relief, had it been known to them. As Marek stated, it is indeed 'more likely' that only the second of these two subscriptions is by Statilius, whereas the first is by an anonymous predecessor. Yet, as I hope to have demonstrated, we can go further than that: the conventional interpretation conflicts with manuscript authority, linguistic usage, and what we know of ancient editorial practice, all of which support the new proposal by Marek. The latter is not just verisimilius: we should accept it without hesitation as the true explanation of the curious notice in Poggio's manuscript.

The intriguing conclusion is that this is not just - as it has conventionally been viewed the oldest editorial subscription to the Latin classics, but the two oldest such notices. And these unique records of the advanced editorial work of the classical era do not just take us back to Statilius in the second century, but to the unknown but even earlier time of the mysterious editor whose text Statilius found and used. By correctly elucidating this short text Marek thus restored a missing link in the 2000-year-old philological tradition to which, as editor of the standard critical text of De lege agraria in our own times, he is the distinguished heir.

\section{REFERENCES}

\section{Manuscripts}

Florence, Biblioteca Medicea Laurenziana, Pluteus 48.26 (consulted in digital images in the Teca Digitale, teca.bmlonline.it [31 December 2015]).

Milan, Veneranda Biblioteca Ambrosiana, C $236 \inf$ (consulted in digital images at Digital Ambrosiana on Internet, dai.ambrosiana.eu [31 December 2015]).

Milan, Veneranda Biblioteca Ambrosiana, C 96 sup (non vidi).

Vatican City, Bibliotheca Apostolica Vaticana, Vaticanus latinus 11458 (consulted directly).

\section{Secondary sources}

Bandini, A. M., 1775. Catalogus codicum latinorum Bibliothecae Mediceae Laurentianae ... Ang. Mar. Bandinius ... edidit. Tomus II. Florentiae: [s. n.].

Bandini, A. M., 1776. Catalogus codicum latinorum Bibliothecae Mediceae Laurentianae ... Ang. Mar. Bandinius ... edidit. Tomus III. Florentiae: [s. n.].

Birt, T., 1882, Das antike Buchwesen in seinem Verhältniss zur Litteratur, mit Beiträgen zur Textgeschichte des Theokrit, Catull, Properz und anderer Autoren. Berlin: Heertz.

Büchner, K., 1961. 'Überlieferungsgeschichte der lateinischen Literatur des Altertums'. In: H. Hunger (ed.), Geschichte der Textüberlieferung der antiken und mittelalterlichen Literatur. Zürich: Atlantis, 309-422.

Cameron, A., 2011. The Last Pagans of Rome. Oxford: Oxford University Press.

Campana, A., 1973. 'La copia autografa delle otto orazioni ciceroniane scoperte da Poggio nel 1417'. Ciceroniana N.S. 1, 65-68 = A. Campana, Scritti. I: Ricerche medievali e umanistiche. Tomo secondo [= Storia e letteratura. Raccolta di studi e testi 240]. Roma: Storia e Letteratura, 2012, 849-852.

Clark, A. C., 1909a. Inventa Italorum [= Anecdota Oxoniensia, classical series 9]. Oxford: Clarendon.

Clark, A. C. (ed.), 1909b. M. Tulli Ciceronis orationes. Vol. IV. Oxonii: ex Typographeo Clarendoniano. 
Coraluppi, L., 1983. 'I manoscritti della famiglia germanica del «de lege agraria» di Cicerone'. ACME. Annali della Facoltà di Lettere e Filosofia dell'Università degli Studi di Milano 36, 147-159.

Coraluppi, L., 1987. 'Marek V. (ed.), M. Tulli Ciceronis Scripta quae manserunt omnia, 16. Orationes de lege agraria, Oratio pro C. Rabirio perduellionis reo'. Rivista di Filologia e di Istruzione Classica 115, 463-473.

De Paolis, P., 2000. 'Cicerone nei grammatici tardoantichi e altomedievali'. Ciceroniana n.s. 11, 37-67.

Du Cange, C., Carpentier, D. P., Henschel, G. A. L., Favre, L., 1883-1887. Glossarium mediae et infimae latinitatis. Niort: L. Favre. Consulted via Du Cange Online, ducange.enc.sorbonne.fr [31 December 2015].

Garin, E. (ed.), 1962. Laurentius Valla, Opera omnia. ... Tomus prior. Scripta in editione Basilensi anno MDXL collecta [= Monumenta politica et philosophica rariora 1.5]. Torino: Bottega d'Erasmo.

Gilles-Raynal, A.-V., Dolbeau, F., Fohlen, J., Riou, Y.-F., Tilliette, J.-Y., 2010. Les Manuscrits classiques latins de la Bibliothèque Vaticane. Tome III. $2^{\text {me }}$ partie. Fonds Vatican latin, 2901-14740. Cité du Vatican: Bibliothèque Apostolique du Vatican / Paris: CNRS Éditions.

Jahn, O., 1851. 'Über die Subscriptionen in den Handschriften römischer Classiker'. Berichte über die Verhandlungen der königlich sächsischen Gesellschaft der Wissenschaften zu Leipzig. Philologisch-historische Classe 3, 327-372.

Kornhardt, H., 1936. Exemplum. Eine bedeutungsgeschichtliche Studie. Dissertation. Göttingen.

Mai, A., 1817. Cicero ambrosianis codicibus illustratus et auctus. M. Tullii Ciceronis sex orationum partes ante nostram aetatem ineditae ... Editio altera ... recensuit ... Angelus Maius. Mediolani: Regiis typis.

Marek, V. (ed.), 1983. M. Tullius Cicero, Orationes de lege agraria. Oratio pro C. Rabirio perduellionis reo [= M. Tulli Ciceronis scripta quae manserunt omnia 16]. Leipzig: Teubner.

Martin, D. E., 1984. 'The Statilius-subscription and the editions of late antiquity'. In: D. F. Bright, E. S. Ramage (ed.), Classical Texts and their Traditions. Studies in Honor of C. R. Trahman. Chico, Calif.: Scholars Press, 147-154.

McDermott, W. C., 1972. 'M. Cicero and M. Tiro'. Historia 21, 259-286.

Merello, M., 1977. 'Statilio Massimo'. Studi e ricerche dell'Istituto di latino. Università di Genova 1, $113-136$.

Pasquali, G., 1971. Storia della tradizione e critica del testo. Seconda edizione. Seconda ristampa. Firenze: Le Monnier.

Pecere, O., 1982. 'La «subscriptio» di Statilio Massimo e la tradizione delle «Agrarie» di Cicerone'. Italia Medioevale e Umanistica 25, 73-123.

Pecere, O., 1986. 'La tradizione dei testi latini tra iv e v secolo attraverso i libri sottoscritti'. In: A. Giardina (ed.), Tradizione dei classici: trasformazione della cultura [= Istituto Gramsci, Seminario di antichistica. Società romana e impero tardoantico 4]. Roma: Laterza, 19-82 and 210-246.

Piacente, L., 1992-1993. 'Cicerone in Aldelmo (e in una subscriptio tardoantica)'. Romanobarbarica 12, $87-100$.

Piacente, L., 2014. 'Quando i copisti... danno i numeri (Aldhelm, de metr. 140)'. In: L. Piacente, Cicerone a riflettori spenti. Episodi della tradizione testuale di orazioni ed epistole [= Quaderni di «Invigilata Lucernis» 45]. Bari: Edipuglia, 87-96.

Pöhlmann, E., 2003. Einführung in die Überlieferungsgeschichte und in die Textkritik der Antike. Zweite Auflage. Darmstadt: Wissenschaftliche Buchgesellschaft.

Reeve, M. D., 1995. 'The familia Cusana of Cicero's speeches De Lege Agraria and In Pisonem'. In: C. Leonardi, B. Munk Olsen (ed.), The Classical Tradition in the Middle Ages and the Renaissance. Proceedings of the first European Science Foundation Workshop on «The Reception of Classical Texts» (Florence, Certosa del Galluzzo, 26-27 June 1992) [= Biblioteca di medioevo latino 15]. Spoleto: Centro italiano di studi sull'alto medioevo, 57-74.

Reynolds, L. D., Wilson, N. G., 2013. Scribes and Scholars. A Guide to the Transmission of Greek and Latin Literature. Fourth edition. Oxford: Oxford University Press.

Rizzo, S., 1973. Il lessico filologico degli umanisti [= Sussidi eruditi 26]. Roma: Storia e Letteratura.

Rizzo, S., 2004. 'I latini dell'umanesimo'. In: G. B. Perini (ed.), Il latino nell'età dell'umanesimo. Atto del Convegno, Mantova, 26-27 ottobre 2001 [= Accademia Nazionale Virgiliana di Scienze Lettere e Arti. Miscellanea 12]. Firenze: Olschki, 51-96.

Röhle, R., 2005. ' "Oratio eximia» : Poggios Randvermerk auf fol. 56v von Vat. Lat. 11458'. Zeitschrift der Savigny-Stiftung für Rechtsgeschichte. Romanistische Abteilung 122, 195. 
Rouse, R. H., Reeve, M. D., 1986. 'Cicero: Speeches’. In: L. D. Reynolds (ed.), Texts and Transmission. A survey of the Latin classics. Reprinted with corrections. Oxford: Clarendon, 54-98.

Ruysschaert, J., 1959. Bibliothecae Apostolicae Vaticanae codices manu scripti recensiti 9, Codices Vaticani Latini 16, Codices 11414-11709. In Biblioteca Vaticana: Typis Polyglottis Vaticanis.

Schanz, M., Hosius, C., Krüger, G., 1922. Geschichte der römischen Literatur bis zum Gesetzgebungswerk Justinians. Dritter Teil. Die Zeit von Hadrian 117 bis auf Constantin 324 [= Handbuch der Altertumswissenschaft 8.3]. Dritte neubearbeitete Auflage. München: Beck (Nachdruck 1959).

Schmidt, P. L., 1997. 'Statilius Maximus' (\$ 445.3). In: K. Sallmann (ed.), Handbuch der lateinischen Literatur der Antike. Vierter Teil. Die Literatur des Umbruchs. Von der römischen zur christlichen Literatur. 117 bis 284 n. Chr. [= Handbuch der Altertumswissenschaft 8.4]. München: Beck, 256-258.

ThLL = Thesaurus Linguae Latinae. Lipsiae; München; Berlin / New York, 1900-.

Timpanaro, S., 1981. La genesi del metodo del Lachmann. Nuova edizione riveduta ed ampliata. Padova: Liviana.

Timpanaro, S., 1986. Per la storia della filologia virgiliana antica [= Quaderni di «Filologia e critica» 6]. Roma: Salerno editrice.

Tonelli, T. (ed.), 1832. Poggii epistolae. ... collegit ... Thomas de Tonellis. Florentiae: typis L. Marchini. [Reprinted in: R. Fubini (ed.), Poggii opera omnia. Vol. 3 [= Monumenta politica et philosophica rariora 2.6]. Torino: Bottega d'Erasmo, 1963.]

Uría Varela, J., 2012. 'Iulius Romanus and Statilius Maximus (Char. Gramm. 252, 14-31): A reappraisal'. Materiali e discussioni per l'analisi dei testi classici 69, 225-238.

Wessner, P., 1930. 'Statilius Maximus' [= Maximus 43]. In: W. Kroll (ed.), Paulys Realencyclopädie der classischen Altertumswissenschaft. Vierzehnter Band. Achtundzwanzigster Halbband. Neue Bearbeitung. Stuttgart: Alfred Drückenmüller, 2571-2572.

Zetzel, J. E. G., 1973. 'Emendavi ad Tironem: some notes on scholarship in the second century AD'. Harvard Studies in Classical Philology 77, 225-243.

Zetzel, J. E. G., 1974. 'Statilius Maximus and Ciceronian studies in the Antonine age'. Bulletin of the Institute of Classical Studies 21, 107-123.

Zetzel, J. E. G., 1981. Latin Textual Criticism in Antiquity. New York: Arno.

\title{
SUBSKRIPCE STATILIA MAXIMA K CICERONOVÝM ŘEČEM DE LEGE AGRARIA
}

Ve své edici Ciceronových řečí De lege agraria z roku 1983 navrhl Václav Marek novou interpretaci subskripce gramatika 2. století n. 1. Statilia Maxima, která je dochována v rukopise s těmito řečmi. V Markově interpretaci je tento důležitý záznam, který je nejstarší známou subskripcí k textům latinských klasiků, mnohem lépe srozumitelný. Jeho výklad ovšem zůstal nepovšimnut a další práce ho nebraly v potaz. $V$ tomto př́spěvku je vysvětleno, proč je třeba dát mu přednost před standardním výkladem, na základě našich znalostí přepisování rukopisů, jazyka a antické editorské praxe.

\author{
Orla Fiona Mulholland \\ Translator \& Editor, Berlin \\ orlamulholland@hotmail.com
}

